\section{FORUM}

Invited article

DOI: http://dx.doi.org/10.1590/So034-759020180302

\title{
WHEN EATING BECOMES BUSINESS
}

\section{MARINA HECK ${ }^{1}$}

marina.heck@heckmail.com ORCID: 0000-0001-5645-3816

\section{JEFFREY PILCHER ${ }^{2}$}

jeffrey.pilcher@utoronto.ca ORCID: 0000-0002-3540-5310

\section{KRISHNENDU RAY 3}

krishnendu.ray@nyu.edu ORCID: 0000-0002-3947-8111

\section{ELIANE BRITO'1}

eliane.brito@fgv.br

ORCID: 0000-0002-7340-1337

${ }^{1}$ Fundação Getulio Vargas, Escola de Administração de Empresas de São Paulo, São Paulo, SP, Brazil

2 University of Toronto, Department of Historical and Cultural Studies,

Toronto, ON, Canada

${ }^{3}$ New York University, Department of Nutrition and Food Studies, New York, NY, United States of America

\section{INTRODUCTION}

Food is big business in both Brazil and around the world. Brazil-based 36 Capital, for example, made news by its purchase of renowned international brands such as Budweiser, Kraft-Heinz, and Burger King. Brazil's current global managerial leadership marks a distinct change from its historical position as a commodity exporter, albeit a dominant one. However, scale is not the only measure of food's economic significance; in modern industrial societies, production and sale of food still provide basic livelihood for countless people, especially the most marginalized, from acai pickers on the Amazonian riverside to artisanal food street vendors in São Paulo. Comprehending the food business requires several analytical tools reaching across both social and geopolitical boundaries. Such analysis must be attuned to the myriad problems of public health and social integration that remain despite-and in some cases have resulted from-the successes of modern agribusiness and industrial food processing. This special issue seeks to introduce the methods and findings in the field of Food Studies to readers of RAE-Revista de Administração de Empresas to encourage international and interdisciplinary conversations leading to better understanding of and innovative practices within the global food system.

The modern food industry has achieved remarkable technical advances to resolve the problems of production, preservation, transportation, and distribution, but it has created many new dilemmas. The fundamental principle behind food industrialization is the commodification process, which transforms the organic diversity of plants and animals into standardized, interchangeable parts (Appadurai, 1986; Giedion, 1948).

Since the 19th century, the elaborate transportation, refrigeration, and financial service infrastructure facilitated global trade in goods such as wheat, coffee, and meat, but these commodities' market efficiency depended on ignoring qualitative differences resulting from place of origin and means of production (Cronon, 1991; Pilcher, 2016). The consumers' cost savings, however, were paid by farmers facing cut-throat competition with producers from around the world, a situation made worse by their weak bargaining power relative to intermediaries who control the trade. Yet, consumers are increasingly rebelling against anonymous products of the globalized, industrial food system.

In the early 2oth century, the global elite were already willing to pay a premium for the guarantee that their sparkling wine came from a particular geographical location, the Champagne district of France (Guy, 2003). Such certifications of origin and production methods have proliferated 
in recent decades, restoring or reinventing identities once erased by commodification, as customers seek foods that reflect their values, such as use of organic methods, fair trade, animal welfare, environmental sustainability, or better taste (Parasecoli, 2017).

Today's industrial systems that transport food globally also gave rise to widespread public health concerns. To meet the unrelenting demand for increased yield, the commodity agriculture system devised multifarious cocktails of fertilizers, pesticides, and herbicides, often posing long-term dangers to the health of consumers, farm workers, and the environment. Likewise, preservatives used by industrial food processors to extend goods' shelf life and allow their global transport often imposed incremental but real threats to public health. The industry also exposes its workers to grave dangers, such as migrant field workers being sprayed by toxic chemicals or slaughterhouse workers wielding sharp knives at the factory's grueling pace (Gray, 2014; Stull \& Broadway, 2004). The scale of mass production has also become a health concern, as contamination from Escherichia coli and other deadly bacteria spreads through food supplies. The industry's desire to shield consumers from knowledge about food production conditions can further hinder efforts to prevent such outbreaks.

Anthropology has linked eating habits to socialization processes. Dietary concerns always existed and were explained culturally. Medical research on agro-industrial processes identified damages that were unknown until recently and raised concerns about their harmfulness (Levenstein, 2012). However, health concerns and particular dietary requirements are becoming increasingly common and tend to individualize meals rather than keep them communal (Fishler, 2013).

In addition to economic and health concerns, food remains central to social issues of race, class, and gender in the modern world. In his influential study, Freyre (1933) considered food a basic element of the race mixture that forged the Brazilian nation. Although scholars critiqued the notion of Brazilian "racial democracy," globally, the culinary "melting pot" was a fundamental trope of social integration in pluralistic societies (Gabaccia, 1998; Heck \& Belluzo, 1998).

Bourdieu (1984) formulated an influential theoretical framework to explain how cultural expressions such as cuisine help maintain and perpetuate social distinctions while analyzing the role of food and other cultural expressions in constructing social class. The Parisian restaurant cuisine observed by Bourdieu in the 1960 s lost its global dominance as "foodies" sought racialized communities or travelled the world pursuing innovative and/or traditional restaurants, and as street foods that were popular and vulgar became trendy and fashionable.
Rather than democratizing the social space of food, sophisticated diners' omnivorous pursuits of authenticity and exoticism distanced consumers from racialized cooks and vendors, thereby naturalizing social distinctions (Johnston \& Baumann, 2010). However, attempts by celebrity chefs and food critics to appropriate and gentrify street food often depended on culinary knowledge and innovation of racialized cooks (Ray, 2016). Thus, in examining the complex social world of cuisine, researchers must combine the perspectives of producers and consumers, as well as discursive and sensory dimensions of food.

Food Studies researchers have an ongoing, collaborative project called City Food, which aims at rethinking culinary differences and identifying food's place in diasporic communities. A global partnership of noted scholars has assembled in the last three years, leading academic programs and centers, museums, and not-for-profit associations with the two-fold objective of increasing collaboration across the Global North-South divide.

One focus of this collaboration is the new seam of research on street vending that shifts attention from the triad of rurality, domesticity, and haute cuisine dominating the field of Food Studies. Because this field was built mostly around Euro-American concerns, it avoided engaging with street food, because street eating has been declining in Europe and North America for the last half century due to affluence, state building, and enclosing of labor and eating. Street food was historically important in the Global North, but most Northern subjects have forgotten its pleasures. Erasure of street food marked the transition from the poor past to the affluent present, and from mobility to rootedness and terroir, within the template of developmentalist delusions of Southern bureaucrats. Street food's death went hand in hand with the reach and power of the modern welfare state, stringent municipal regulation, and total risk management. Pursuing the pleasures of street food changes the flavor of the politics and poetics of good taste; decolonizes the palatal and philosophical expectations of gastronomy that have come to dominate the field since 18th century France; and marks the transition from 2oth-century welfare politics to an unchartered world of microentrepreneurship, risk, and precarity into the 21st century. Viewed from the bottom up, the study of street food mostly concerns the sustainable livelihoods of poor people and palatal pleasures of poor and not-so-poor people in a matrix of cross-class interests, ethics, and aesthetics.

Theorizing pleasure via street food also allows scholars to escape the shadow of Bourdieu, consumed by the question of domination in democracies. It allows a richer and deeper description of our subjects. Ignoring joy and pleasure may be written into the very DNA of critique and critical analysis 
in scholarly literature-perhaps born from Frankfurt School's pessimism regarding popular culture-where outrage and anger against the system are the only legitimate affects allowed in the toolkit of the sullen analyst. Democracies are in peril everywhere, and they need scholars' analytical and affective investment. Scholars need to change their tune. In this collaborative project, the researchers hope to make room for the epistemology of joy under the concepts of liveliness and live-ness of street vending and eating. Only time will tell if they can find that opening. Restaurants, cookshops, and street vendors are the loci of everyday multiculturalism that could be a hedge against totalitarian ambitions of purified peoples with unadulterated and domesticated cultures. The quotidian business of street food is a repository of cultural democracy at work in the Global South, and there is much to learn from it.

This special issue of $R A E$ received 47 submissions. This shows that a Business Administration journal is open and eager to discuss the "food business" issue. Besides the seven articles approved, the issue presents an invited article from Jeffrey Pilcher about his ongoing research on beer.

\section{ACCEPTED ARTICLES}

The question of identity and cultural conflict over foodways is examined by Leela Riesz's “Convivencia: A solution to the halal/pork tension in Spain?” which examines Spain's iconic dish, ham, and Muslim immigrants' avoidance of pork products. The author shows how restaurateurs seeking social integration have started innovating by creating halal ham. This way, they reinterpret histories of social conflict between Christians and Muslims (and also Jews) in the Iberian Peninsula. Although this is often viewed in terms of Reconquista, immigrants seek instead to recall the Convivencia. Through ethnographic field work in Muslim restaurants in southern Spanish cities of Sevilla and Almería, the author reworks historical memories together with practical matters of separate butchers and cooking pots in communal kitchens. Amongst the challenges faced, this study shows how a Tunisian immigrant created halal jamón ibérico to gain a sense of belonging, and also cautions that not all Muslims find this acceptable. This article points to avenues for co-existence in foodways and other living together issues.

In Latin America, Lima in Peru represents a phenomenal gastronomical boom. Peru branded its cuisine by combining international culinary training with ancient Incan authenticity. In "The presentation of the chef in everyday life: Socializing chefs in Lima, Peru," Amy Lasater-Wille conducted ethnographic research in Lima for 16 months and examined socialization practices in two culinary schools, which included classes on self-presentation so students become capable of self-promotion, to elucidate how culinary work is linked to person formation in Peru. This formation is regarded essential to promote the national brand. Professionalizing the chef as a model citizen for interacting with the global environment, encouraging entrepreneurship, and constraining social practices considered deleterious could be the path for success.

As consumers become more affluent, they raise expectations regarding animal welfare and environmental protection, and the industry must consider this. The exploratory study, "Animal-derived food industry: Risks and opportunities due to farm animal welfare," by Thomas Michael Hoag and Celso Funcia Lemme attempts to map the agendas of companies in the industry and compares them with agendas of principal stakeholders to better understand the risks and opportunities facing companies' intangible assets regarding farm animal welfare.

The paper by Patricia Silva Monteiro Boaventura, Carla Caires Abdalla, Cecilia Lobo Araújo, and José Sarkis Arakelian, "Value co-creation in the specialty coffee value chain: The thirdwave coffee movement," shows how Brazil, like other commodity exporters, relied on international markets, booms, and busts, because such goods were considered interchangeable. Coffee may be incorporated into the list of foods seeking to create value through strategies such as terroir (taste of place) that break the commodity's anonymity. The article highlights challenges in differentiating products through presenting higher quality or introducing the idea of unique experience.

Raising similar questions about high-value foods, “Legitimacy as a barrier: An analysis of Brazilian premium cocoa and chocolate legitimation process" by Marina Henriques Viotto, Bruno Sutil, and Maria Carolina Zanette uses institutional theory to examine the legitimacy of Brazilian premium cocoa. Legitimization of a product's value involves several actors that must build a cultural-cognitive framework to recognize and differentiate the products. This process is educational in nature and involves not only producers but also media and the creation of new consumption trends.

Considering the scenario of gentrified Californian cities, Alison Hope Alkon in her paper "Entrepreneurship as activism? Resisting gentrification in Oakland, California" identifies entrepreneurship as a form of opposition to gentrification. As observed in the contemporary foodie society, authenticity is created through associations with the gritty culture of lower classes. Yet, multiple forms of this authenticity are often in conflict. Authenticity derives from the presence of not only gritty, racialized 
working classes but also cultural elites navigating the streets and curating the nature of public space (Zukin, 1996). These activist-entrepreneurs of food outlets create employment and business opportunities for the area's residents. The author shows how food-based entrepreneurs run successful businesses that, simultaneously, are also political projects.

Modernization is always seeking to impose sanitation on traditional foodways, particularly street foods. In Singapore, creation of hawker courts was considered a solution to not only the problem of sanitation but also social integration in a society with a delicate balance of ethnic groups. However, the article "Hawkerpreneurs: Hawkers, entrepreneurship, and reinventing street food in Singapore” by Nicole Tarulevicz identifies a new problem. These hawker courts were hugely successful, but a generation later, there was no form of social reproduction of the hawker population a generation later. As this generation is not substituted easily, there is an attempt to attract workers through the allure of entrepreneurship. The main foci of this article are historical perspectives on the food hawking evolution in Singapore and the meaning of entrepreneurship and narratives of people who were successful but pursued the hawker life.

\section{INVITED ARTICLE}

In their essay "Beer with Chinese characteristics: Marketing beer under Mao," Jeffrey M. Pilcher, Yu Wang, and Yuebin Jackson Guo explain how a western consumer good became the most popular alcoholic beverage in Communist China. Although economists pointed to market reforms of Deng Xiaoping as the onset of China's beer industry, the authors take a historical perspective to show that the groundwork for contemporary advances was laid under Mao. Using a culinary infrastructure framework, the authors conduct cultural analysis of beer marketing campaigns while focusing on the material conditions of production. The authors conclude that the Chinese Communist Party inculcated a taste for beer not through capitalist advertising campaigns but through non-market forms of conspicuous consumption as an urban privilege in a society defined by scarcity.

\section{PERSPECTIVES, ESSAYS, BOOK REVIEW, AND BOOK RECOMMENDATIONS}

The Perspectives section has two authors who write about the same subject. The article "How Big Business got Brazil Hooked on Junk Food" published by The New York Times on September 16,2017 , raised an important question about changes relative to health issues such as increase in diabetes and obesity on populations that recently began consuming industrialized food (Nestle, 2003). We used this article for discussion in this section and invited Richard Wilk and Ana Paula Bortoletto Martins to comment.

Two Essays are presented by Lucy M. Long and Carlos Alberto Dória that, though quite different, seem to converse. Both authors are researchers on food from ethnic and anthropological perspectives. Long's essay regards the question of ingredient diffusion through culinary tourism and the interest in what the author calls food otherness. Today, food is not only an issue of taste, hospitality, and health but also an attraction driving tourism and other commercial enterprises. Food festivals, cooking classes, and market tours are important parts of local business and can change local economy. Dória's essay is on the historical dimension that focuses on the diffusion of culinary ingredients and how they appear in dishes of different people. It is well-known that there was a dispersion of animals and vegetables during the period when Portuguese navigators discovered and settled in Asia, Africa, and Latin America. Recently, we observe a diffusion of dishes that combine different ingredients, and it is unknown how they got together. Doria's essay shows that studies on diffusion of ingredients rarely consider the historical long-term perspective of how foodstuffs were incorporated in the diets of disparate cultures. Culinary tourism transforms food into something more than a commodity. It is an experience that, when lived, will increase what Bourdieu (1970) calls cultural capital.

Krishnendu Ray wrote the Book Review for this issue. The book A History of the World in Seven Cheap Things: A Guide to Capitalism, Nature, and the Future of the Planet by Raj Patel and Jason W. Moore shows how seven things-nature, money, work, care, food, energy, and lives-shape the world's future. Together with the history of colonialism, they examine latest sustainability studies to analyze today's world emergencies. The book proposes a radical way of dealing with today's global ecological crises.

The Book Recommendations section shows the partnership between two educational institutions: New York University (NYU) and Fundação Getulio Vargas (FGV) in Sao Paulo, through collaboration between their graduate students. Noah Allison, an NYU graduate student, and the other by Adriana Schneider Dallolio, an FGV graduate student. Both students are doctoral candidates, and the recommendations reflect their readings for their research work. 


\section{REFERENCES}

Appadurai, A. (Ed.). (1986). The social life of things: Commodities in cultural perspective. Cambridge, MA: Cambridge University Press.

Bourdieu, P. (1984). Distinction: A social critique of the judgment of taste (R. Nice, Trans.). Cambridge, MA: Harvard University Press.

Bourdieu, P., \& Passeron, J. P. (1970). La reproduction. Paris, France: Ed Minuit.

Cronon, W. (1991). Nature's metropolis: Chicago and the Great West. New York, NY: Norton.

Fishler, C. (2013). Les alimentations particulieres: Mangerons nous encore ensemble demain?. Paris, France. Odile Jacob.

Freyre, G. (1933). Casa-Grande e Senzala: Formacao da familia brasileira sob o regime de economia patriarchal. Rio de Janeiro, Brazil: Jose Olympio.

Gabaccia, D. R. (1998). We are what we eat: Ethnic food and the making of Americans. Cambridge, MA: Harvard University Press.

Giedion, S. (1948). Mechanization takes command: A contribution to anonymous history. New York, NY: Oxford University Press.

Gray, M. (2014). Labor and the Locavore: The making of a comprehensive food ethic. Berkeley, CA: University of California Press.
Guy, K. M. (2003). When champagne became French: Wine and the making of a national identity. Baltimore, MD: Johns Hopkins University Press.

Heck, M., \& Belluzo, R. (1998). Cozinha dos imigrantes: Memorias \& receitas. São Paulo, Brazil: DBA Melhoramentos.

Johnston, J., \& Baumann, S. (2010). Foodies: Democracy and distinction in the gourmet foodscape. New York, NY: Routledge.

Levenstein, H. (2012). Fear of food: A history of why we worry about what we eat. Chicago, IL: University of Chicago Press.

Nestle, M. (2003). Safe food: Bacteria, biotechnology, and bioterrorism. Berkeley, CA: University of California Press.

Parasecoli, F. (2017). Knowing where it comes from: Labeling traditional foods to compete in a Global Market. University of lowa Press. Iowa

Pilcher, J. M. (2016). Culinary infrastructure: How facilities and technologies create value and meaning around food. Global Food History, 2(2), 105-131. doi:10.1080/20549547.2016.1214896

Ray, K. (2016). The ethnic restaurateur. London, UK: Bloomsbury.

Stull, D., \& Broadway M. (2004). Slaughterhouse blues: The meat and poultry industry in North America. Belmont, CA: Wadsworth.

Zukin, S. (1996). The culture of the cities. Cambridge, MA: Blackwell Publishers. 